\title{
The organization of testicular interstitial tissue and changes in the fine structure of the Leydig cells of European moles (Talpa europaea) throughout the year
}

\author{
Fumie Suzuki and P. A. Racey* \\ Department of Anatomy, School of Medicine, Chiba University, Chiba 280, Japan and \\ * Department of Zoology, University of Aberdeen, Aberdeen AB9 2TN, U.K.
}

\begin{abstract}
Summary. Seasonal changes of the testicular interstitial tissue were studied by electron microscopy. During the breeding season in spring, clusters of Leydig cells are surrounded by wide lymphatic sinusoids. In sexually quiescent moles, these sinusoids collapse, and the abundant Leydig cells become closely packed and occupy most of the testis. During sexual activity, the Leydig cells contain abundant smooth endoplasmic reticulum (SER), mitochondria with tubular cristae, and lipid droplets. Some areas of the cytoplasm are occupied exclusively by tubular SER, arranged in parallel. During regression the SER appears tortuous, and large lipid droplets are found in the cytoplasm, although these gradually become smaller. During the long period of sexual quiescence, the size and abundance of Leydig cells and the appearance of SER, lipid droplets and mitochondria were similar to those observed during sexual activity.
\end{abstract}

\section{Introduction}

Changes in the Leydig cells of seasonally breeding mammals have been reviewed by Christensen (1975). Leydig cells develop from undifferentiated cells in the interstitial tissue before the breeding season, and mature into steroid-secreting cells with abundant smooth endoplasmic reticulum (SER), mitochondria with tubular cristae, and lipid droplets. At the end of the breeding period the cells regress, commonly accumulate many large lipid droplets containing cholesterol and other substrates no longer required for steroid synthesis, and return to the undifferentiated state from which they will develop again the following season. In the rock hyrax (Procavia habessinica) the development of the Leydig cells coincides with an increase in plasma testosterone level (Neaves, 1973). The European mole (Talpa europaea) has a short breeding season; spermatogenesis reaches its peak during March in England and the accessory organs show parallel annual activation and regression (Allanson, 1963; Godfrey \& Crowcroft, 1960; Suzuki \& Racey, 1976), reflecting seasonal changes in androgen levels (Racey, 1978). It was therefore of interest to examine the fine structure of the Leydig cells throughout the year in an attempt to establish the differences between the active and regressed states. Some observations of the fine structure of mole Leydig cells have been made (Aumüller \& Schäfer, 1972), but these were limited to the period of regression. The organization of the interstitial tissue and associated lymphatic system has been studied in various mammalian species by Fawcett, Neaves \& Flores (1973), and this aspect of the mole testis was also examined in the present study.

\section{Materials and Methods}

Fifty-one male moles were caught at intervals of about 6 weeks throughout 1 year in the vicinity of Stallmine, Lancashire, England $\left(53^{\circ} 54^{\prime} \mathrm{N}, 2^{\circ} 57^{\prime} \mathrm{W}\right)$ and 23 were used for the present study. They were transported to the Unit of Reproductive Biology in Liverpool, and killed by decapitation. Immediately after death the testes were removed, incised to facilitate penetration of fixative, and immersed in $2.5 \%$ phosphate-buffered glutaraldehyde, $\mathrm{pH} 7 \cdot 3$, for about $24 \mathrm{~h}$. After fixation, small 
pieces of tissue were taken from the area close to the incision, and washed briefly in phosphate buffer before being post-fixed in $1 \%$ phosphate-buffered osmium tetroxide, dehydrated in ethanol and embedded in Epon 812. Thick sections, cut with glass knives, were stained with methylene blue and examined with a light microscope. Thin sections, cut with a diamond knife, were mounted on coated copper grids, stained with aqueous uranyl acetate followed by lead citrate and examined in a JEM 7A or Hitachi HS-11 DS electron microscope.

\section{Observations}

\section{Organization of the interstitial tissue and associated lymphatics}

The configuration of the Leydig cells and the width of the lymph spaces changed markedly during the breeding cycle. There was very little connective tissue in the intertubular area throughout the year. In March, when spermatogenic activity was at a maximum, the mean diameter of the seminiferous tubule was $220 \mu \mathrm{m}$. During April, the seminiferous tubules still showed full spermatogenic activity, but had a slightly reduced mean diameter of $190 \mu \mathrm{m}$. In May, the testis had become greatly reduced in size, and most spermatozoa had been released. During these months the Leydig cells occurred in clusters of various sizes between seminiferous tubules (Pl. 1, Figs 1 and 2). Intertubular blood vessels were intimately associated with the Leydig cells, although some appeared solitary in cross-sections. An irregular gap was present between the Leydig cell cluster and the adjacent seminiferous tubules. In the electron microscope, this gap was distinguished as a lymphatic sinusoid (P1. 1, Fig. 1) because a very thin endothelium was closely applied to the peritubular layer of myoid cells. This peritubular investment was so closely juxtaposed to the myoid cells that it was difficult to resolve as a separate layer with the light microscope. A thin layer of endothelium, cytologically similar to the peritubular investment, was also seen around the blood vessels and the Leydig cell cluster (Pl. 1, Fig. 1; Pl. 2, Fig. 5).

Spermatogenic activity was negligible from July to January. The tubular diameter during this period was only about $25 \%$ of that during spermatogenesis, and the increased area of testicular interstitium was occupied with abundant closely packed Leydig cells (Pl, 1, Fig. 3). The lymphatic sinusoidal space of the spermatogenically inactive testis was narrower than during sexual activity, except in some moles caught in July, although no significant change appeared in the lymphatic endothelial cells of the peritubular investment (Pl. 3, Fig. 7). Such cells were frequently encountered among the Leydig cells, and their thin layer of cytoplasm often intervened between adjacent Leydig cells (Pl. 3, Fig. 6). Spermatogenesis began again in February, and although the tubular diameter increased to a mean of $110 \mu \mathrm{m}$, no conspicuous change occurred in the organization of the interstitial tissue at this time.

\section{Fine structure of the Leydig cells}

For convenience of description mole testes were classified into four stages: the active stage (from March to April), the regression stage (from May to July), the quiescent stage (from August to January) and the developing stage (February).

The active stage. Microvilli and ruffling were present on the surface of the Leydig cells except where they adjoined the neighbouring cells (Pl. 2, Fig. 4). The most striking feature is the smooth endoplasmic reticulum (SER), which extended throughout much of the cytoplasm, and consisted of tortuous tubules or of gently curved tubules arranged in parallel (PI. 4, Fig. 9). The outer diameter of these tubules was 40-50 nm, and many contained electron-dense material ( $\mathrm{Pl}$. 4, Fig. 10), which appeared as an indistinct thin filament in longitudinal section (Pl. 4, Fig. 11). The parallel SER occurred more often in the periphery of the cell, to the exclusion of other organelles, except for a few ribosomal particles. At the periphery, the membranes of the straight tubules were continuous with those of the tortuous SER (PI. 4, Fig. 9), indicating that the parallel arrangement was a regional modification. The proportion of the two types of SER varied from one cell to another. Free ribosomal particles were abundant around the nucleus and around the poorly developed cisternae of the granular 
endoplasmic reticulum, and relatively common around the tortuous SER. The mitochondria were circular or elliptic in cross-section and varied considerably in size from about 0.6 to $2.7 \mu \mathrm{m}$ in their shorter diameter. The mitochondrial cristae were predominantly tubular although some vesicular or foliate cristae were also present. Osmiophilic lipid droplets, generally not more than $3 \mu \mathrm{m}$ in diameter, were scattered among the mitochondria. The nucleus, with a prominent nucleolus, was generally situated eccentrically, and the Golgi apparatus with small clear vesicles appeared in the central area of the cell. A few lipofuscin pigment granules were also encountered (Pl. 2, Fig. 4).

The regression stage. In May, many large lipid droplets, frequently exceeding $10 \mu \mathrm{m}$ in diameter, accumulated in the cytoplasm of the Leydig cell (Pl. 1, Fig. 2; Pl. 2, Fig. 5). Large droplets were frequently of low electron density, although the density of smaller droplets varied. The cytoplasm was still largely occupied with SER, but the parallel arrangement was seldom observed, although a complicated regular array of SER was occasionally present during May (PI. 5, Fig. 12) when a few membrane-bound autophagic vacuoles also appeared (Pl. 2, Fig. 5 inset). The amount of lipofuscin pigment increased slightly during this stage. In July, the Leydig cells of some individuals were similar to those in May and others resembled the quiescent stage. In both types, many lipid droplets were still present but their size was greatly reduced.

The quiescent and the increasing stages. In these stages, the characteristics of the Leydig cells, e.g. size, amount and appearance of SER, mitochondria with tubular cristae, and large nuclei with prominent nucleoli, resembled those of the active stage (Pl. 3, Figs 6 and $8 ;$ Pl. 5, Fig. 13). In the quiescent stage, discrete bundles of SER were found among the tortuous and the parallel SER (PI. 3, Fig. 6). The majority of lipid droplets were dense and small in size, but a small number of large droplets remained in the Leydig cells of sexually quiescent moles.

\section{Discussion}

The organization of testicular interstitial tissue and the associated lymphatic system was classified by Fawcett et al. (1973) into three types: (1) few Leydig cells and very little connective tissue stroma but with extensive peritubular lymphatic sinusoids or lymph spaces occupying a large part of the intertubular area: (2) clusters of Leydig cells scattered in abundant connective tissue which is drained by a lymphatic vessel: and (3) abundant closely packed Leydig cells occupying nearly all the enlarged intertubular areas, but with little connective tissue and very small interstitial lymphatics. The organization of the interstitial tissue of the mole, however, could not be classified as one of these three types: as far as the organization of the lymphatics is concerned, it clearly falls in the first type, although the width of the sinusoids is reduced during sexual quiescence. If classified according to the abundance of Leydig cells, sexually active moles can be placed into the second category, since the expansion of the seminiferous tubules separates the Leydig cells into clusters. Sexually quiescent moles fall into the third category, because the abundant and closely packed Leydig cells occupy nearly all the intertubular area (Pl. 1, Fig. 3).

Large increases in the testosterone content of the testes are associated with spermatogenesis in all mammals so far investigated, including moles (Racey, 1974, 1978), and the Leydig cells may be expected to show associated changes in fine structure. However, mole Leydig cells in the quiescent stage appear similar to those in the active stage. In addition, the Golgi complexes and mitochondria show no obvious changes throughout the year, although there is some evidence of remodelling, involving rearrangement of SER and the accumulation of lipid droplets, concurrent with the cessation of spermatogenesis.

Several authors, after examining Leydig cells in seasonally breeding mammals, recognize changes of size corresponding with changing testosterone production (Virginia and Sika deer: Wislocki, 1949; roebuck: Short \& Mann, 1966; rock hyrax: Neaves, 1973). However, Buss \& Johnson (1967) and Johnsen (1962) considered that androgen production by the Leydig cells could not be correlated with their histological appearance. Light microscopy has shown that the Leydig cells of the mole do not change significantly in size throughout the year (Courrier, 1927; Lofts, 1960). The present work confirms this and shows that the SER fills much of the cytoplasm, and the large cell size during sexual quiescence is mainly the result of an abundant SER content. 
When SER is observed in mole Leydig cells throughout the year, it appears that the parallel and the tortuous forms are interconvertible, since the parallel form temporarily disappears during the regression stage. Christensen (1965) has also suggested that the tubular and cisternal SER in the guinea-pig Leydig cell may be freely interconvertible. Neaves (1973) found the two forms together only in the non-breeding rock hyrax; in the breeding hyrax, all SER occurred as uniform tubules, suggesting that this was associated with increased steroidogenesis. This was clearly not the case in the

\section{EXPLANATION OF PLATES}

\section{PLATE 1}

Fig. 1. Electron micrograph of testicular interstitial tissue in a sexually active mole during March. The Leydig cells appear in clusters, closely associated with a blood vessel (lower right). Note the virtual absence of connective tissue. Extremely thin processes of lymphatic endothelium are seen around the blood vessel, the Leydig cell cluster and the peritubular layer of myoid cells (arrows). ST, seminiferous tubule; LSS, lymphatic sinusoidal space. $\times 2400$.

Fig. 2. Photomicrograph of mole interstitial tissue during sexual regression in May. Large lipid droplets appear as white spots in the cytoplasm of the Leydig cells. $\times 380$.

Fig. 3. Photomicrograph of interstitial tissue during the sexually quiescent stage. There is no spermatogenic activity in the seminiferous tubules (ST). Numerous Leydig cells are packed together within the intertubular space, and no lymphatic sinusoidal space is visible in the light microscope. $\times 380$.

\section{PLATE 2}

Fig. 4. Electron micrograph of Leydig cells of a sexually active mole. The nucleus, with its prominent nucleolus, is situated eccentrically. A large area of cytoplasm is occupied exclusively by smooth endoplasmic reticulum (SER). Elsewhere, small dense lipid droplets are interspersed with mitochondria. Occasional lipofuscin pigment granules are evident (arrow). $\times 5500$.

Fig. 5. Electron micrograph of Leydig cells during sexual regression in May (the same animal as shown in Fig. 2). Larger lipid droplets have a lower electron density. All SER appears tortuous, and the parallel form (see Figs 9-11 and 13) is rare. Lipofuscin pigment granules (arrows) are more frequently encountered than in the active stage. The left part of the central Leydig cell is covered with the thin cytoplasmic projection of a lymphatic endothelial cell. $\times 5500$. Inset: autophagic vacuole seen in the cytoplasm. $\times 55000$.

\section{PLATE 3}

Fig. 6. Electron micrograph of Leydig cells separated by thin cytoplasmic projections of the lymphatic endothelium during sexual quiescence. The cytological configuration is fundamentally similar to that of the active Leydig cells shown in Fig. 4. The small dense spherical bodies are lipid droplets. The arrows show the discrete bundles of SER which are shown at higher magnification in the inset. $\times 5500$; inset $\times 63000$.

Fig. 7. The lymphatic endothelial cell of the peritubular investment in the sexually quiescent mole. It shows no significant difference from that of the sexually active mole. ST, seminiferous tubule; MC, myoid cell; LE, lymphatic endothelium; LSS, lymphatic sinusoidal space. $\times 6500$.

Fig. 8. Electron micrograph of Leydig cells of a mole caught in February, during the increasing stage. The cytological configuration appears fundamentally similar to that in active and quiescent animals (see Figs 4 and 6). G, Golgi apparatus. $\times 5500$.

\section{PLATE 4}

Fig. 9. Peripheral part of a Leydig cell in a sexually active mole, showing a typical cytoplasmic segregation. The central area of this field is completely occupied with parallel SER. Most of the tubules are cut obliquely, and they are continuous with tortuous SER at the periphery, $\times 25000$.

Figs 10 and 11. Cross sections (Fig. 10) and longitudinal sections (Fig. 11) of the parallel SER in the Leydig cell of the sexually active mole. The outer diameter of each tubule is about $40-50 \mathrm{~nm}$. An amorphous substance is present in the inter- and intra-tubular spaces. In Fig. 11 the intratubular material appears as a thin filament (arrows). Fig. 10, $\times 100000$; Fig. 11, $\times 72000$.

\section{PLATE 5}

Fig. 12. Complicated regular arrays of SER seen in the Leydig cell of the sexually regressing mole caught in May. These arrays may be transitional between the parallel and the tortuous SER. They appear temporarily at the beginning of the regression period: at this time the parallel SER disappears and only the tortuous form occurs during regression. $\times 50000$.

Fig. 13. Longitudinal and cross section of parallel SER in the sexually quiescent mole. Although testosterone production is at a very low level during this period, the SER is well developed and appears morphologically similar to that of the active stage (see Figs 9-11). $\times 40000$. 

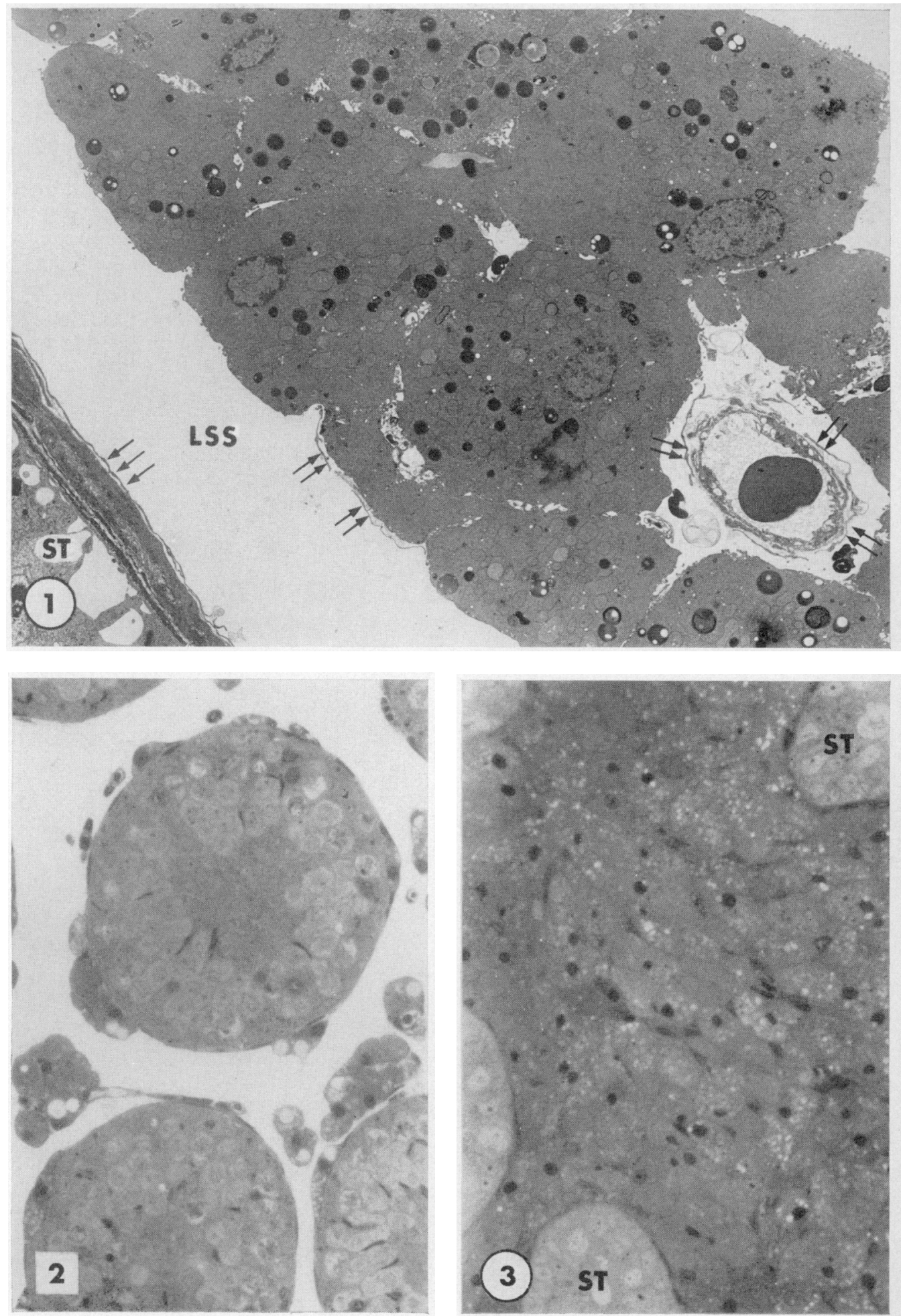
PLATE 2
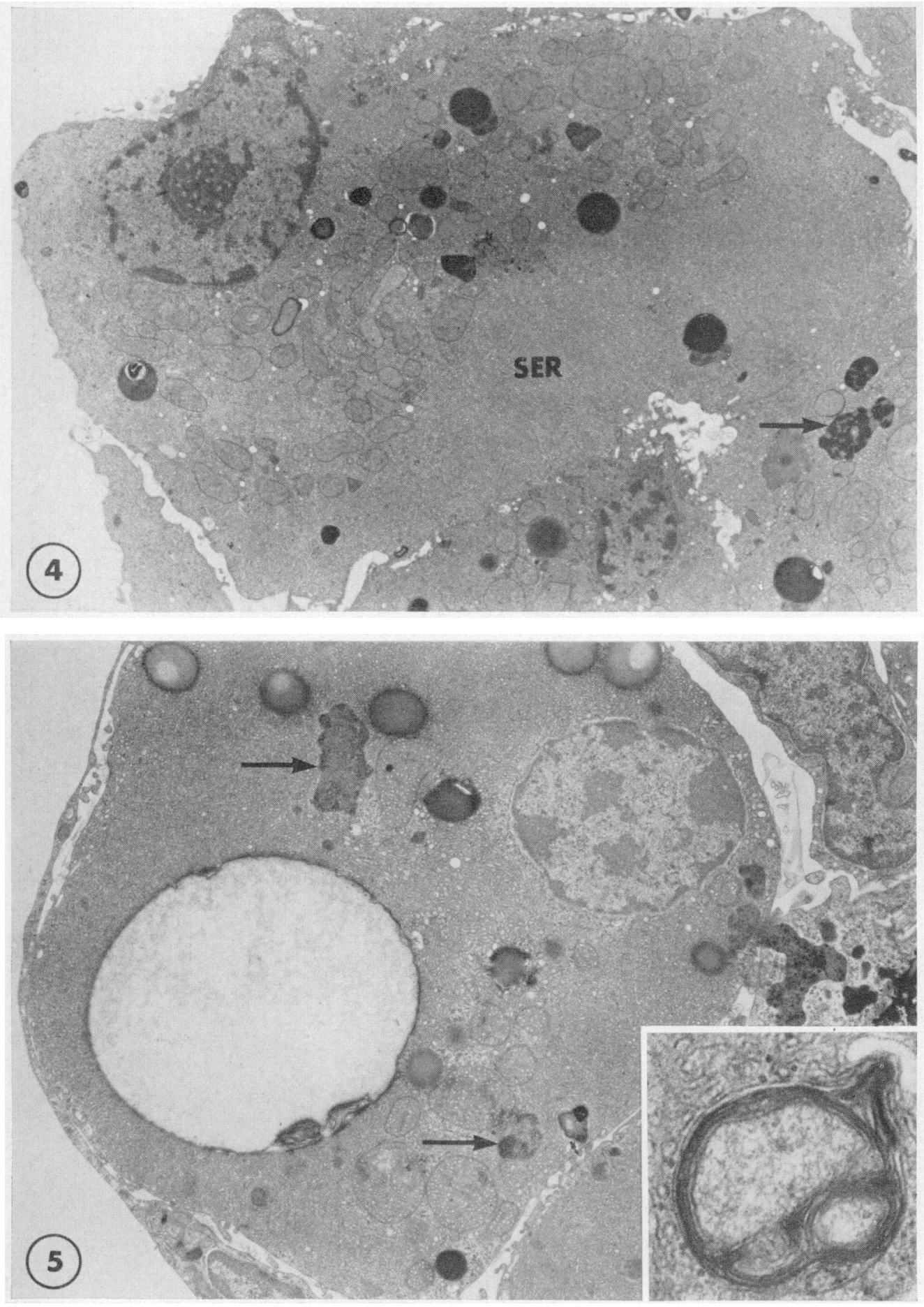

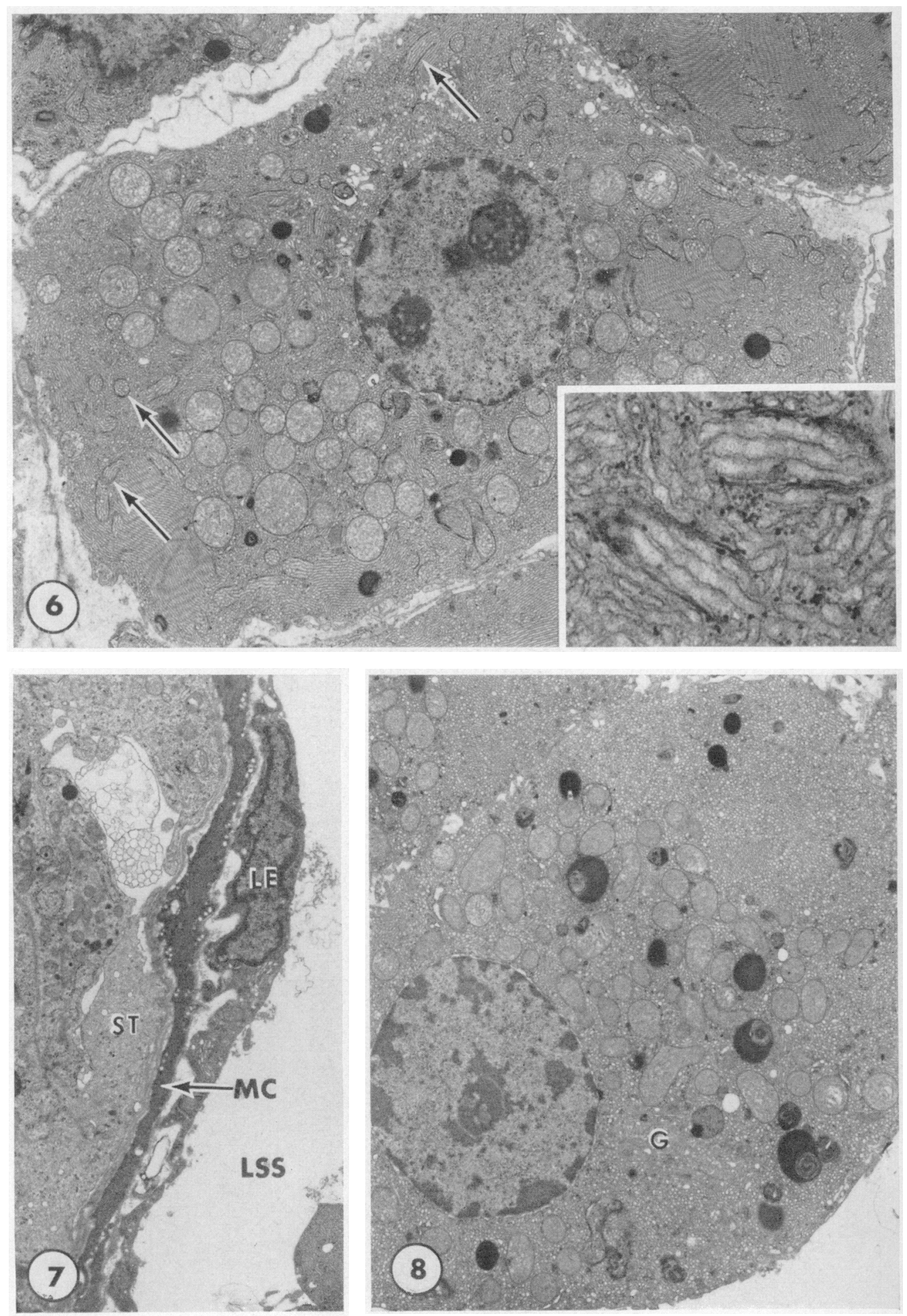

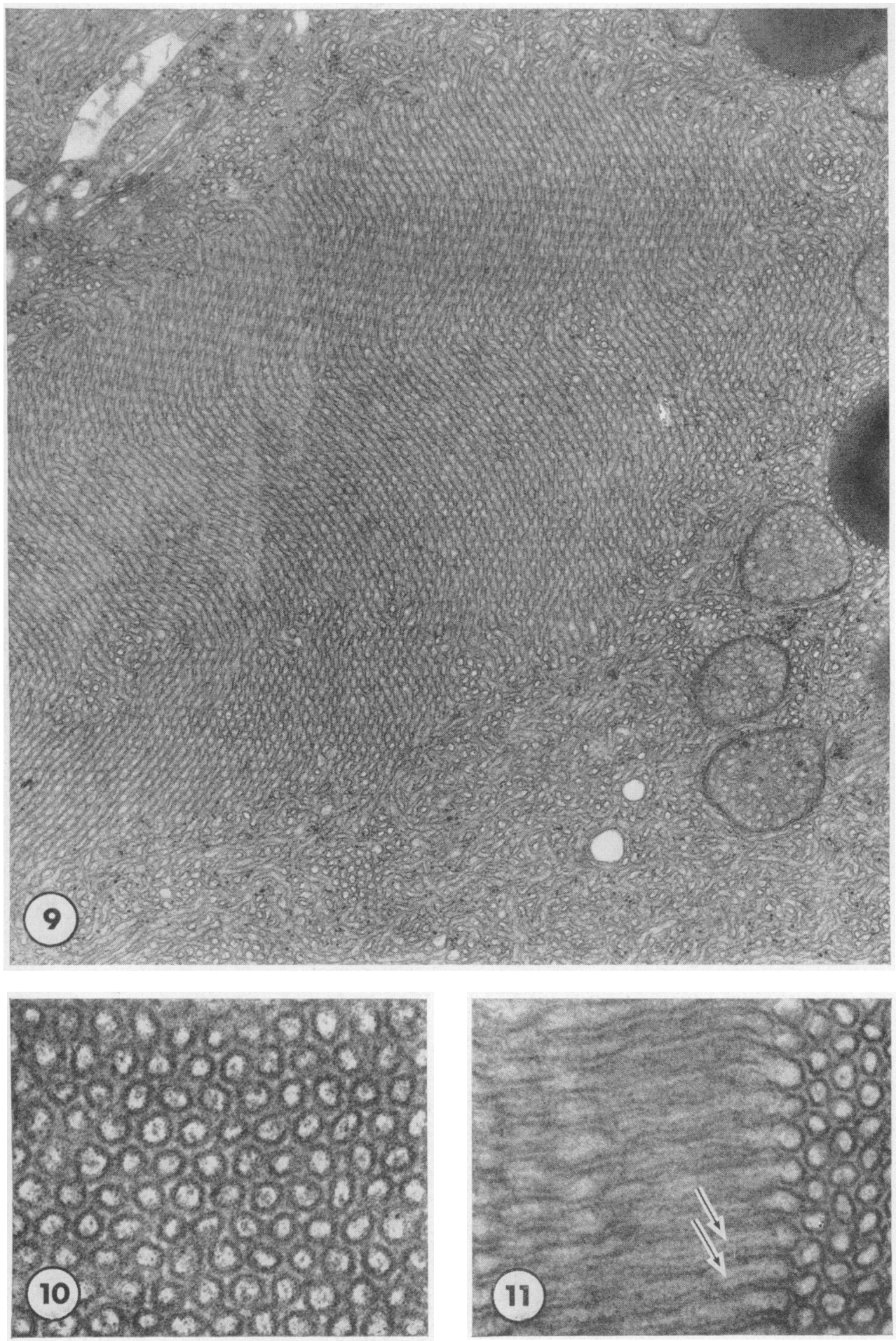

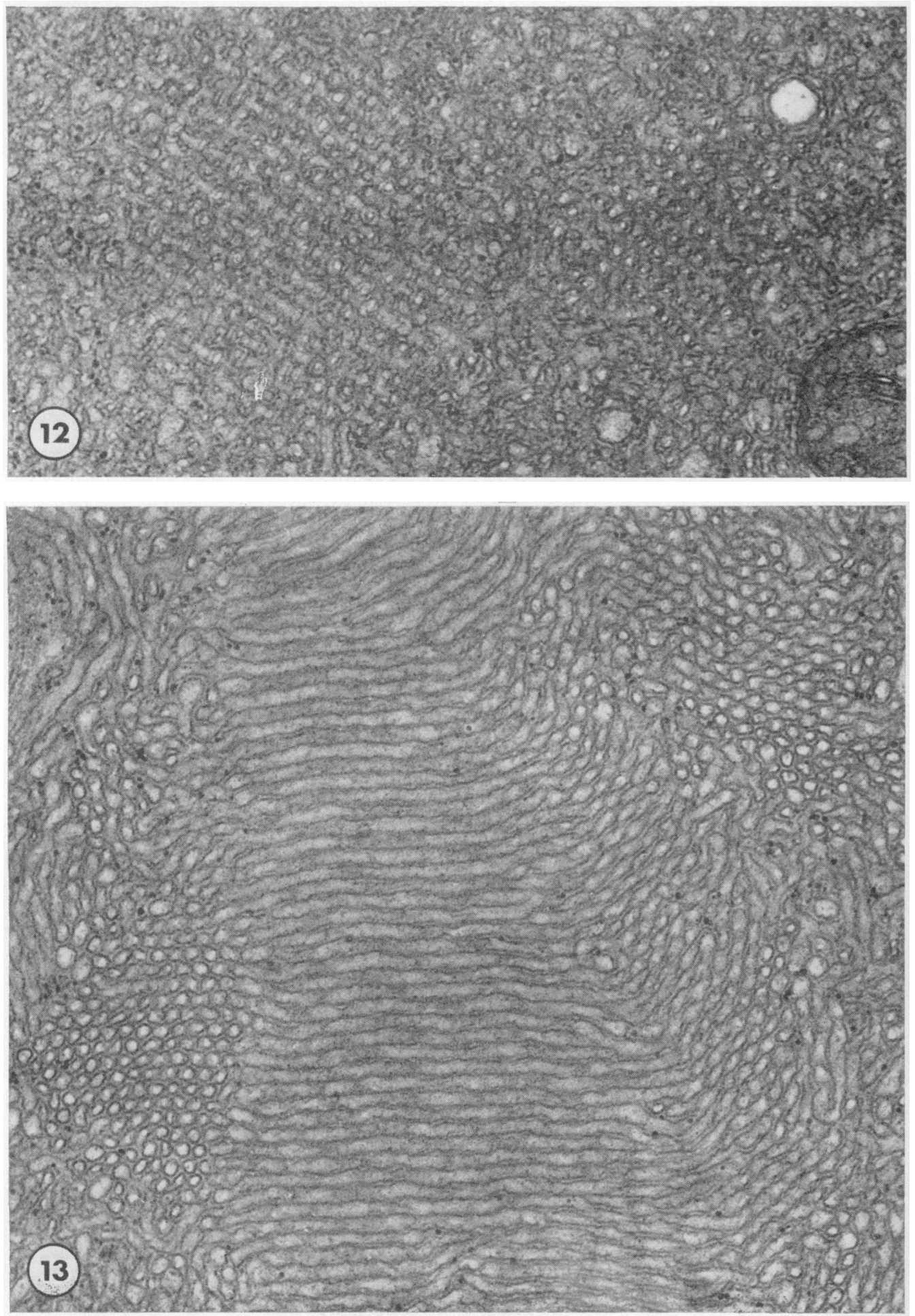
mole, because parallel SER is abundant during sexual quiescence, when hormone production is low (Racey, 1978). Aumüller \& Schäfer (1972) examined mole Leydig cells during one of the four stages considered in the present work, i.e. the regression stage from May to July, and they also found abundant SER, although they believed that this diminished as regression advanced, an observation which was not confirmed by the present work.

The region of parallel SER was completely devoid of other cell organelles. Such 'compartmentation' of the cytoplasm was first reported in mouse Leydig cells by Christensen \& Fawcett (1966). Later, Ichihara (1970) found that such 'compartmentation' became gradually clearer during postnatal development of mouse Leydig cells, which attain adult form at 28 days of age. In the rock hyrax, Neaves (1973) found that the distinct 'compartmentation' of the cytoplasm was associated with the increase in SER during the breeding season, but its significance in steroidogenesis is obscure. As has been pointed out by Christensen \& Fawcett (1966), 'compartmentation' may even be inconvenient for spermatogenesis because the cholesterol side-chain cleavage system is localized in mitochondria, at least in rats (Toren, Menon, Forchielle \& Dorfman, 1964), necessitating transport of substrate from mitochondria to SER. Aoki \& Massa (1972) found accentuated segregation of agranular endoplasmic reticulum from other cytoplasmic organelles after treatment of adult mice with methallibure, which inhibits gonadotrophic activity. However, in the mole the 'compartmentation' was seen to a similar degree both in the active and quiescent stages. The spatial separation between mitochondria and SER, therefore, does not seem to be adequate to explain the reduced testosterone levels during the nonbreeding season (Racey, 1978).

The most significant of the present observations is the abundance of SER during the non-breeding season. In general, the amount of SER is a good indicator of steroidogenesis. Neaves (1973) found a significant positive correlation between the plasma testosterone level and the quantity of SER in the rock hyrax. During puberty, which is analogous to the developing stage of seasonal breeders, the SER in mice increases with androgen production (Ichihara, 1970). It also increases after treatment with gonadotrophin (rat: Murakami \& Tonutti, 1966; man: de Kretser, 1967; guinea-pig: Merkow, Acevedo \& Slifkin, 1968a, b; immature Mongolian gerbils: Merkow, Acevedo, Slifkin \& Pardo, 1969; immature mice: Aoki, 1970). However, such alterations in the abundance and fine structure of SER do not accompany the hormonal changes associated with the annual reproductive cycle in the mole.

This work was initiated at the Unit of Reproductive Biology, University of Liverpool, and supported by grants from the Ford Foundation and the Japanese Ministry of Education. We thank Professor T. D. Glover and Professor T. Nagano for their interest in this study, and Professor D. W. Fawcett for his criticism of the manuscript.

\section{References}

AOKI, A. (1970) Hormonal control of Leydig cell differentiation. Protoplasma 71, 209-225.

AOKI, A. \& MASSA, E.M. (1972) Early responses of testicular interstitial cells to stimulation by interstitialcell-stimulating hormone. Am. J. Anat. 134, 239-262.

Allanson, M. (1963) The reproductive tract of pubertal and mature male moles during anoestrus. $J$. Endocr. 26, ix-x.

Aumüller, G. \& Schäfer, A. (1972) Histochemie und Feinstruktur der Zwischenzellen des Maulwurfhodens (Talpa europaea L., Insectivora, Mammalia) während der Abklingphase der Spermiogenese. Acta histochem. 43, 235-253.

Buss, I.O. \& Johnson, O.W. (1967) Relationship of Leydig cell characteristics and intertesticular testosterone levels to sexual activity in the African elephant. Anat. Rec. 157, 191-196.
Christensen, A.K. (1965) The fine structure of testicular interstitial cells in guinea pigs. J. Cell Biol. 26, 911935.

Christensen, A.K. (1975) Leydig cells. In Handbook of Physiologv, Vol. V, Male Reproductive System, pp. 57-94. Eds D. W. Hamilton \& R. O. Greep. American Physiological Society, Washington, D.C.

Christensen, A.K. \& Fawcetr, D.W. (1966) The fine structure of testicular interstitial cells in mice. Am.J. Anat. 118, 551-572.

COURRIER, R. (1927) Etude sur le déterminisme des caractères sexuels secondaires chez quelques mammifères à activité testiculaire périodique. Archs Biol. 37, 173-334.

DE KRETSER, D.M. (1967) Changes in the fine structure of human testicular interstitial cells after treatment with human gonadotrophins. Z. Zellforsch. mikrosk. Anat. 83, 344-358. 
Fawcetr, D.W., Neaves, W.B. \& Flores, M.N. (1973) Comparative observations on intertubular lym. phatics and the organization of the interstitial tissue of the mammalian testis. Biol. Reprod. 9, 500-532.

Godfrey, G. \& Crowcroft, P. (1960) The Life of the Mole. Museum Press, London.

ICHIHARA, 1. (1970) The fine structure of testicular interstitial cells in mice during postnatal development. $Z$. Zellforsch. mikrosk. Anat. 108, 475-486.

JoHNSEN, S.G. (1962) The management of male hypogonadism. A clinical endocrinological synopsis. Acta endocr., Copenh., Suppl. 66, 1-72.

LofTs, B. (1960) Cyclical changes in the distribution of the testis lipids of a seasonal mammal (Talpa europaea). Q. Jl microsc. Sci. 101, 199-205.

Merkow, L., Acevedo, H.F. \& Slifkin, M. (1968a) Studies on the interstitial cells of the testis. I. The ultrastructure in the immature guinea pig and the effect of stimulation with human chorionic gonadotropin. Am. J. Path. 53, 47-61.

Merkow, L., Acevedo, H.F. \& Slifkin, M. (1968b) Studies on the interstitial cells of the testis. 1I. The ultrastructure in the adult guinea pig and the effect of stimulation with human chorionic gonadotropin. Am. J. Path. 53, 989-1007.

Merkow, L., Acevedo, H.F., Slifkin, M. \& Pardo, M. (1969) Studies on the interstitial cells of the testis. III. The ultrastructure in the immature Mongolian gerbil and the effect of stimulation with human chorionic gonadotropin. Am. J. Path. 57, 581-595.

Murakami, M. \& TonutTI, E. (1966) Submikroskopische Veränderungen der Leydigzellen des Rattenhodens nach Behandlung mit Östrogenen und nach Gonadotropinzufuhr. Endokrinologie 50, 231-250.

Neaves, W.B. (1973) Changes in testicular Leydig cells and in plasma testosterone levels among seasonally breeding rock hyrax. Biol. Reprod. 8, 451-466.

RACEY, P.A. (1974) The reproductive cycle in male noctule bats, Nyctalus noctula. J. Reprod. Fert. 41, 169-182.

RACEY, P.A. (1978) Seasonal changes in testosterone levels and androgen-dependent organs in male moles (Talpa europaea). J. Reprod. Fert. 52, 195-200.

SHORT, R.V. \& MANN, T. (1966) The sexual cycle of a seasonally breeding mammal, the roebuck (Capreolus capreolus). J. Reprod. Fert. 12, 337-351.

SUZUKI, F. \& RACEY, P.A. (1976) Fine structural changes in the epididymal epithelium of moles throughout the year. $J$. Reprod. Fert. 47, 47-54.

Toren, D., Menon, K.M.J., Forchielle, E. \& DorfMAN, R.I. (1964) In vitro enzymatic cleavage of the cholesterol side chain in rat testis preparations. Steroids 3, 381-390.

WisLockI, G.B. (1949) Seasonal changes in the testis, epididymides, and seminal vesicles of deer investigated by histochemical methods. Endocrinology 44, 167-189.

Received 19 April 1977 